\title{
The Effect of Combined Oral Contraceptive Pills on Factor VII Activity and D-dimer Level in Healthy and Obese Women
}

\author{
Israa S. Abbas* \\ Haithem A. Al-Rubaie** \\ Jaffar N. Jaffar Alsaidissa**
}

\author{
MBChB, MSc \\ MBChB, FICMS \\ MBChB, PhD
}

J Fac Med Baghdad 2016; Vol.58, No.1 Received Oct. 2015 Accepted Nov. 2015

Background: The combined pill includes a combination of an estrogen and a progestin. Users of these pills have an increased risk of developing thrombotic disorders compared to the non-users. Obesity is an independent risk factor for venous thromboembolism. Obesity with oral contraceptive use increases the risk of thrombosis furthermore.

Objectives: To assess the effects of these pills in obese and healthy non-obese women on factor VII activity and D-dimer level. Also to compare the thrombophilic effects of combined pills in women with control group of normal healthy non-users women.

Patients and Methods: This study was started on November 2014 and completed on March 2015, and included 50 females attended at Baghdad Teaching Hospital. They were using contraceptive pills (Microgynon ${ }^{\circledR}$ ED Fe) for at least 3 months. Females were divided into 2 equal groups; the non-obese group and the obese group. As well 25 non-obese age-matched non-pregnant females not on contraception or taking any hormonal therapy were recruited as a control. The hemostatic parameters done for them included the prothrombin time, activated partial thromboplastin time, factor VII, D-dimer level, and platelet count.

Results: There were significant reductions in prothrombin time in both the non-obese and obese groups compared to the control $(\mathrm{P}=0.014$ and 0.020 , respectively). The correlations between the duration of pills use and clotting times both showed insignificant differences in the study groups. The factor VII activity in the non-obese and obese groups were significantly higher than that of the control $(\mathrm{P}=0.041$ and 0.001 , respectively). There were also significant increase in $\mathrm{D}$-dimer levels in the non-obese and obese groups compared to the control $(\mathrm{P}=0.029$ and 0.038 , respectively). The platelet count was significantly increased only in the obese group compared to the control $(\mathrm{P}=0.027)$.

Conclusion: The use of the combined oral contraceptive pills (Microgynon ${ }^{\circledR} \mathrm{ED} F \mathrm{Fe}$ ) is associated with significant increase in factor VII activity and the level of D-dimer that may lead to enhanced procoagulant activity. Therefore, females should be properly assessed and monitored before starting using the pills and while on them.

Keywords: Combined oral contraceptive pills, Obesity, Factor VII, D-dimer.

\section{Introduction:}

The combined oral contraceptive pill (COCP) is usually known as the birth control pill [1]. Females using the COCP have 2- to 7-fold increased risk of developing deep vein thrombosis (DVT) and pulmonary embolism (PE) compared to that in non-users females [2,3]. The first report of thrombosis associated with COCPs was a PE in 1961 in a nurse shortly after starting its use for the treatment of endometriosis [2]. The mechanism of the increased thrombotic risk is that the estrogens content in the pills have many effects on coagulation system that results in shifting of the hemostatic balance toward a prothrombotic state, these include the increased levels of the prothrombin, fibrinogen, factors VII, VIII, IX, X, XI, XII, and XIII and with reduced

* Abi-Ghraib Hospital.

**Dept. of Pathology/College of Medicine /University of Baghdad. Email: israasaadi2013@yahoo.com
$\mathrm{S}$ and antithrombin, and acquired resistance to activated protein $\mathrm{C}$ that underlies the major COCPs' thrombogenic potential [2,4-6]. However, the levels of antithrombotic proteins are also changed enhancing fibrinolysis, including increased levels of protein $\mathrm{C}$, alpha-antitrypsin and plasminogen, with reduced levels of plasminogen activating inhibitor-1 [5,6]. The venous thromboembolism (VTE) risk in COCP users is highest during the first year of using the pills, but it is not cumulative with longer use and returns to baseline shortly after discontinuation of using the pills. This risk is increased with age and with increasing estrogen dose [2,4,7-9].Obesity is defined by World Health Organization (WHO) as abnormal or excessive fat accumulation that may impair health [10]. Body mass index (BMI), the simple index of weight-for-height is commonly used to classify overweight and obesity. It is calculated by dividing the 
person's weight in kilograms by the square of his height in meters $\left(\mathrm{kg} / \mathrm{m}^{2}\right)$. The normal BMI is $18.5-24.9 \mathrm{~kg} / \mathrm{m}^{2}$. The overweight is when the BMI is greater than or equal to $25 \mathrm{~kg} / \mathrm{m}^{2}$. While a BMI greater than or equal to $30 \mathrm{~kg} /$ $\mathrm{m}^{2}$ is regarded as obesity $[10,11]$. It is an independent risk factor for VTE and increases the risk of thrombosis 2-fold $[2,12,13]$, since obese individuals have higher levels of the procoagulant factors VII, VIII, XII and fibrinogen [12]. Another study found that obese individuals had higher levels of factors VIII and IX, but not of fibrinogen [13]. There may be an additional risk of thrombosis caused by venous stasis that also occurs with obesity [12]. Oral contraceptive use in conjunction with obesity increases the risk of thrombosis about 10-fold [2,5,12,13].Factor VII is a vitamin $\mathrm{K}$-dependent clotting factor. It is synthesized primarily in the liver. It has the shortest half-life of all the clotting factor zymogens ( 3 to 6 hours). Its function is to serve as an initiator of the extrinsic pathway of coagulation when bound to its membrane cofactor, tissue factor [14]. The $\mathrm{D}$-dimer antigen is unique marker of fibrin degradation which is formed by the sequential action of three enzymes; thrombin, activated factor XIII and plasmin. D-dimer measurement has been clinically utilized mainly for the exclusion of VTE [15]. Elevated D-dimer levels are seen in disseminated intravascular coagulation, arterial and venous thrombosis, septicemia, cirrhosis, carcinoma, sickle cell crisis, and following operative procedures [16].

Aim of the study: This study is designed to assess the effect of using combined oral contraceptive pills on factor VII activity and D-dimer level in healthy non-obese women and obese women. Also to compare the possible thrombophilic effects of combined pills in women with control group of normal healthy non-users women.

\section{Patients and methods:}

This prospective case-control study was done over a period of 4 months, started on 11 November 2014 and completed on 11 March 2015. This study included 50 females attended the family planning clinic at Baghdad Teaching Hospital of Medical City. They were regularly using monophasic regular dose estrogen containing COCP (Microgynon $^{\circledR}$ ED Fe composed of $0.03 \mathrm{mg}$ ethinylestradiol and $0.15 \mathrm{mg}$ levonorgestrel, a second generation progestin) for at least 3 months and up to 8 years. Their ages were between 18 and 45 years. Females on COCP were divided into two groups:

Non-obese group: enrolled 25 females with BMI of $<30 \mathrm{~kg} /$ $\mathrm{m}^{2}$ (15/25 females were overweight, and 10/25 had normal weight).

Obese group: composed of 25 females with BMI of $\geq 30$ $\mathrm{kg} / \mathrm{m}^{2}$.
A 25 -healthy, non-obese (16/25 were overweight and 9/25 had normal weight), age-matched non-pregnant females not on COCP nor taking any hormonal therapy and having no history of malignancy or previous thrombosis were assigned as a control group for comparison with the study group.Data collected from each participant included the name, age, duration of pills use, medical history (hypertention, diabetes, rheumatoid arthritis, previous thrombosis), the time for the last surgical procedure (if present), drug history, smoking history, recent trauma, prolonged air travel, features of PE (shortness of breath, cough with bloody mucus, chest pain, fainting spells, dizziness), and features of DVT (redness, warmth, tenderness, and swelling of the leg). Weight was measured with electronic balance, and height was measured with the subject barefooted and her back facing the wall using a calibrated rod, then the BMI was calculated for each. By a clean aseptic venipuncture $4.3 \mathrm{ml}$ of blood were drawn from each patient and control groups. The sample was then divided between two tubes:

$>2.5 \mathrm{ml}$ of blood in dipotassium ethylene diamine tetraacetic acid ( $\mathrm{K}_{2}$-EDTA) tube for platelet count (PLT) which were performed using automated analyzer (Cell-DYN, RUBY ABBOTT Diagnostic, USA).

$>1.8 \mathrm{ml}$ of blood in disposable capped plastic tube containing $0.2 \mathrm{ml}$ of $109 \mathrm{mmol} / \mathrm{l}$ trisodium citrate dihydrate $(32 \mathrm{~g} / \mathrm{l})$ and gently mixed well by inverting several times.Platelets poor plasmas (PPP) were prepared by centrifugation of blood at $2000 \mathrm{~g}$ for 15 minutes [17]. Then $0.3 \mathrm{ml}$ of PPP was obtained from the upper part of the separated plasma for performance of prothrombin time (PT), activated partial thromboplastin time (APTT), and for factor VII activity within 2 hours of blood collection using STart $4{ }^{\circledR}$ semi-automated coagulometer (Diagnostica Stago, France). The remaining PPP was stored in eppendorf tubes at $-20^{\circ} \mathrm{C}$ for measuring D-dimer level later on (within less than 4 weeks), which was performed by turbidimetric immunoassay using Quantia D-Dimer reagent on the automated architect c4000. The normal reference value for D-dimer is $\leq 250 \mathrm{ng} / \mathrm{ml}$ D-dimer units (DDU), or $\leq 0.5 \mu \mathrm{g} /$ $\mathrm{ml}$ fibrinogen equivalent units (FEU) [18].

Statistical analysis: The data were analyzed using SPSS22 and included the descriptive measures of frequency, percentages, meanandstandarddeviation.Pearsoncorrelation was used to measure the relationship between two variables Pearson's correlation coefficient was tested using Student's t-test and was presented in a scatter diagram. Two tailed t-test was applied for testing the significance of difference of two independent sample means of the quantitative data. $P$ value $<0.05$ was considered significant. 


\section{Results:}

A. Age and BMI. The non-obese and obese groups were agedmatched with control group with no statistical significant differences ( $\mathrm{P}$-values $=0.289$ and 0.33 , respectively). The difference in mean BMI of the non-obese group and control group was statistically insignificant $(\mathrm{P}=0.917)$. The difference between mean BMI of the obese group $\left(34.40 \pm 4.36 \mathrm{~kg} / \mathrm{m}^{2}\right.$ and control $26.12 \pm 3.1 \mathrm{~kg} / \mathrm{m}^{2}$ was statistically significant with P-value 0.000 (Table 1).

Table 1 The clinical data (mean values \pm SD) of the study groups and control

\begin{tabular}{|c|c|c|c|c|}
\hline Clinical & \multicolumn{2}{|c|}{ Study groups } & \multirow{3}{*}{$\begin{array}{c}\begin{array}{c}\text { Control } \\
\text { group } \\
n=25\end{array} \\
28.88 \pm 7.59\end{array}$} & $\mathbf{P}$ \\
\hline \multirow{2}{*}{$\begin{array}{c}\text { Age } \\
\text { (years) }\end{array}$} & Non-obese $(n=25)$ & $31.12 \pm 7.17$ & & 0.289 \\
\hline & Obese $(n=25)$ & $33.16 \pm 6.08$ & & 0.33 \\
\hline \multirow{2}{*}{$\begin{array}{c}\text { BMI } \\
\left(\mathrm{kg} / \mathrm{m}^{2}\right)\end{array}$} & Non-obese $(n=25)$ & $26.21 \pm 2.84$ & \multirow{2}{*}{$26.12 \pm 3.1$} & 0.917 \\
\hline & Obese $(n=25)$ & $34.40 \pm 4.36$ & & $0.000 *$ \\
\hline
\end{tabular}

*Significant using independent sample t-test. SD, standard deviation; $n$, number of females

B. The hemostatic parameters of the study groups.

1. Prothrombin time. The mean of PT of the non-obese and the obese groups (12.3 \pm 0.9 and $12.4 \pm 0.7$ seconds, respectively) were significantly shorter than that of the control $(12.9 \pm 0.7$ seconds) with P-values 0.014 and 0.020 , respectively (Table 2).
Table 2 The hemostatic parameters (mean values \pm SD) of the study groups and control

\begin{tabular}{|c|c|c|c|c|}
\hline $\begin{array}{l}\text { Hemostatic } \\
\text { Parameter }\end{array}$ & \multicolumn{2}{|c|}{ Study groups } & $\begin{array}{c}\text { Control group } \\
(n=25)\end{array}$ & P value \\
\hline \multirow{2}{*}{ PT (seconds) } & Non-obese & $12.3 \pm 0.9$ & \multirow{2}{*}{$12.9 \pm 0.7$} & $0.014 *$ \\
\hline & Obese & $12.4 \pm 0.7$ & & $0.020 *$ \\
\hline \multirow{2}{*}{$\begin{array}{c}\text { APTT } \\
\text { (seconds) }\end{array}$} & Non-obese & $28.8 \pm 2.8$ & \multirow{2}{*}{$29.6 \pm 2.8$} & 0.344 \\
\hline & Obese & $28.4 \pm 2.9$ & & 0.151 \\
\hline \multirow{2}{*}{$\begin{array}{l}\text { FVII activity } \\
\text { (\%) }\end{array}$} & Non-obese & $81.2 \pm 13.7$ & \multirow{2}{*}{$73.7 \pm 11.2$} & 0.041 * \\
\hline & Obese & $88.9 \pm 19.4$ & & $0.001 *$ \\
\hline \multirow{2}{*}{ PLT $\left(\times 10^{9} / \mathrm{L}\right)$} & Non-obese & $305.960 \pm 65.999$ & \multirow{2}{*}{$279.40 \pm 46.329$} & 0.106 \\
\hline & Obese & $313.480 \pm 58.468$ & & $0.027 *$ \\
\hline \multirow{2}{*}{$\begin{array}{l}\text { D-dimer (ng/ } \\
\text { ml) }\end{array}$} & Non-obese & $212.8 \pm 122.5$ & \multirow{2}{*}{$155.8 \pm 31.6$} & 0.029* \\
\hline & Obese & $301 \pm 338.8$ & & $0.038 *$ \\
\hline
\end{tabular}

*Significant using independent sample t-test at 0.05 level

It had been observed that $7 / 25(28 \%)$ of females in the nonobese group and 4/25 (16\%) of females in the obese group had shortened PT compared to the lower limit of PT in the control group (11.8 seconds).

$>$ The correlation between the prothrombin time and duration of COCPs use. By dividing the cases according to their duration of pills use, 11/50 females used the pills for $<1$ year, and the remainder used them for $\geq 1$ year. No significant correlation has been shown between PT and duration of COCPs use of $<1$ year with $\mathrm{P}$-value 0.823 , or $\geq 1$ year with $\mathrm{P}$-value 0.601 (Figure 1, A and B).

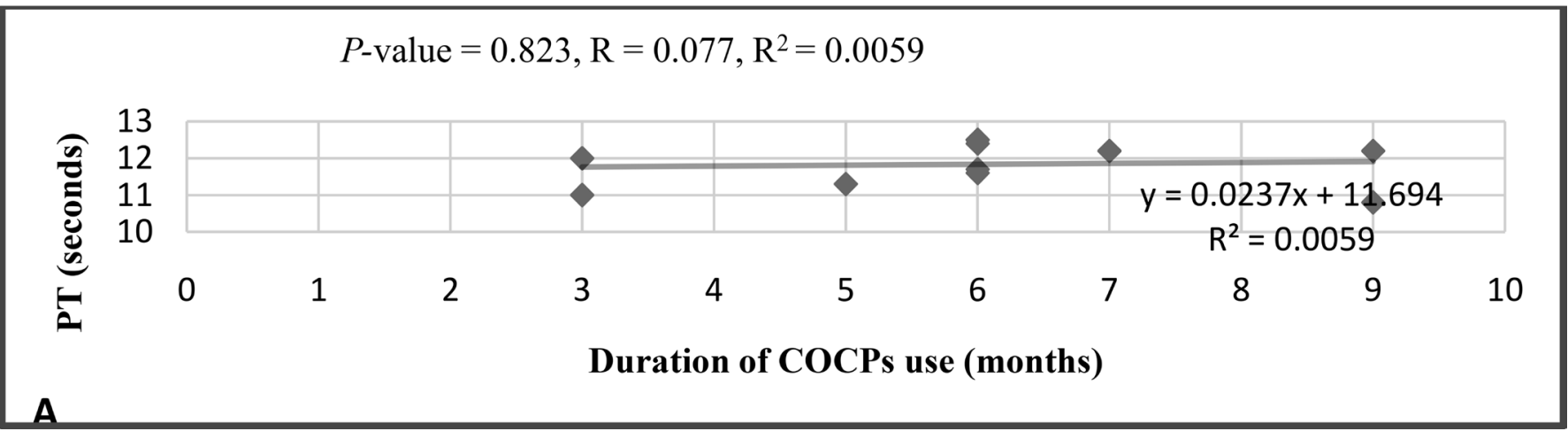




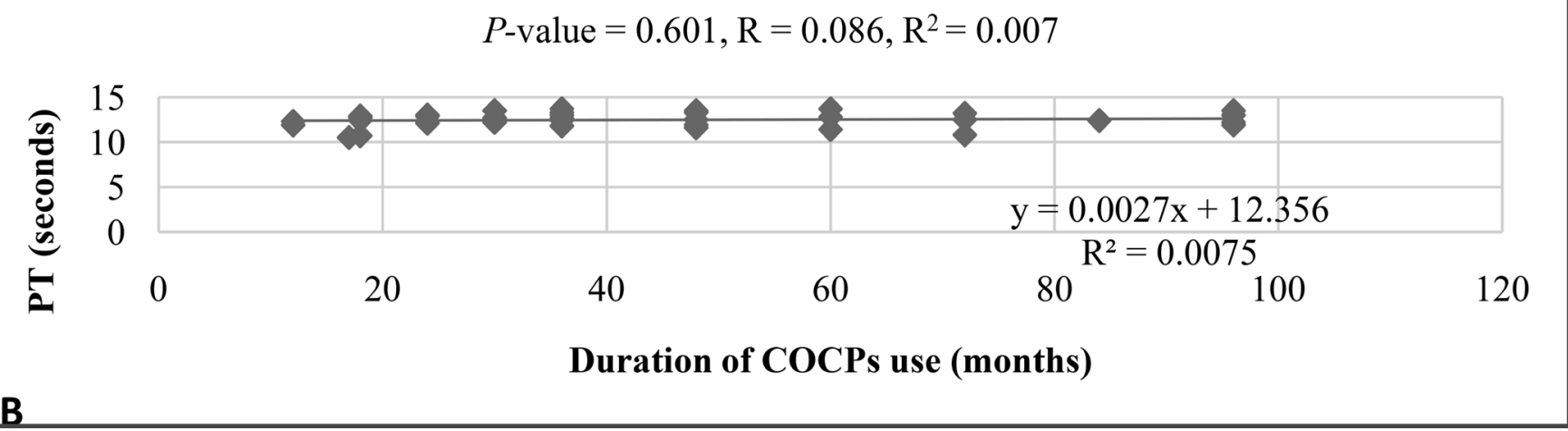

Figure 1 The correlation between the prothrombin time and duration of COCPs use.

$A, 1$ year; $B, \geq 1$ year

2. Activated partial thromoboplastin time. The mean APTT were insignificantly shorter in both the non-obese and the obese groups ( $28.8 \pm 2.8$ and $28.4 \pm 2.9$ seconds, respectively) compared with that of control group $(29.6 \pm 2.8$ seconds $)$ with P-values 0.344 and 0.151 , respectively (Table 2). However, the shortened APTT compared with the lower limit of APTT in the control group ( 24.6 seconds) had been recorded in $8 \%$ of females in each of the non-obese and obese groups.
The correlation between the activated partial thromboplastin time and duration of COCPs use. Insignificant negative correlations between the APTT and the duration of pills use were observed both during the first year and with prolonged use of $\geq 1$ year with P-values 0.068 and 0.314 , respectively (Figure 2, A and B).

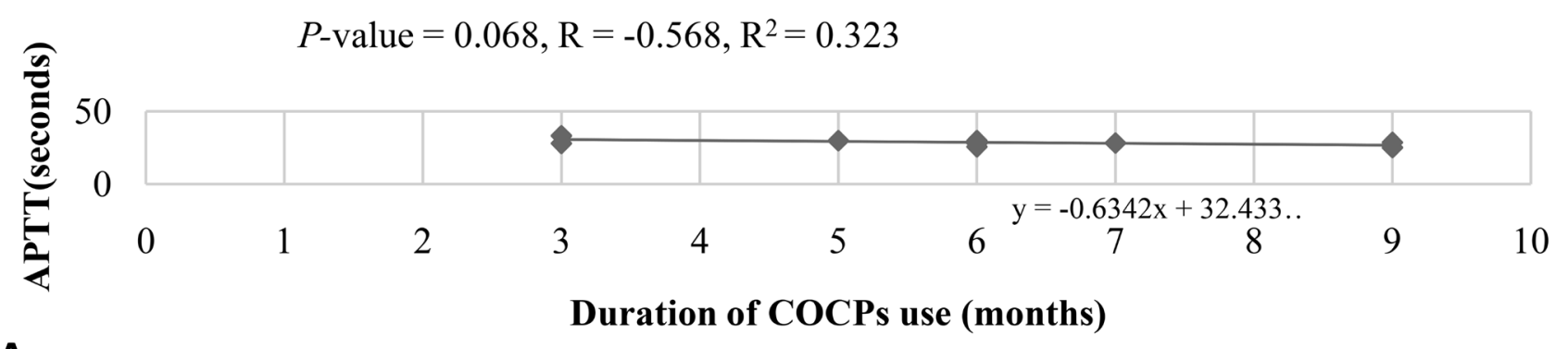

A

Duration of COCPs use (months)

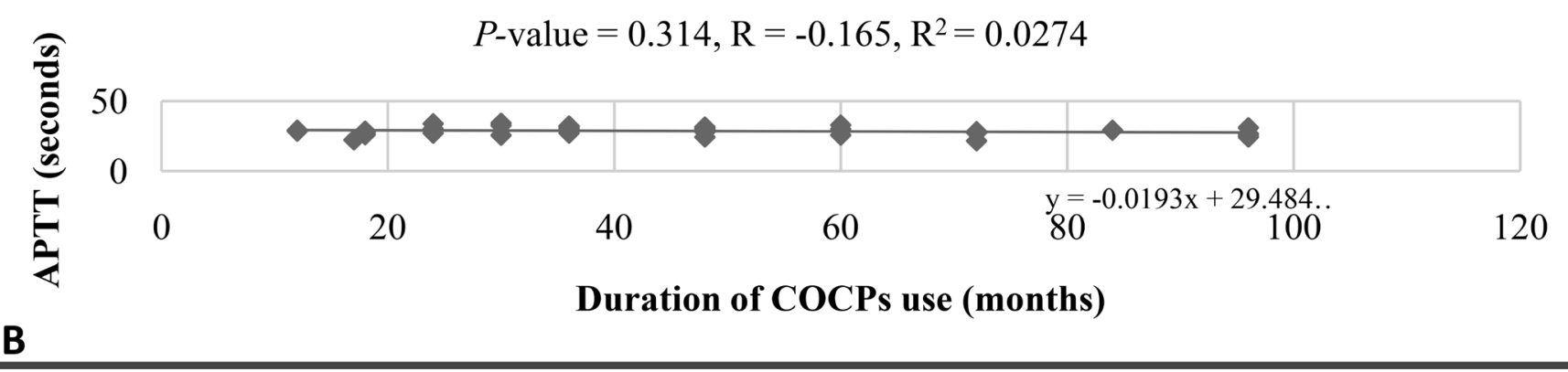

Figure 2 The correlation between the activated partial thromboplastin time and duration of COCPs use. A, 1 year; B, $\geq 1$ year

3. Factor VII activity. The mean of factor VII activity of both the non-obese and the obese groups $(81.2 \pm 13.7 \%$ and $88.9 \pm$ $19.4 \%$, respectively) were significantly higher than that of the control group $(73.7 \pm 11.2 \%)$ with P-values 0.041 and 0.001 , respectively (Table 2 ).
The correlation between FVII activity \% and prothrombin time. For all 50 cases studied, there was significant inverse correlation between FVII activity \% and PT with P-value 0.008 (Figure 3). 


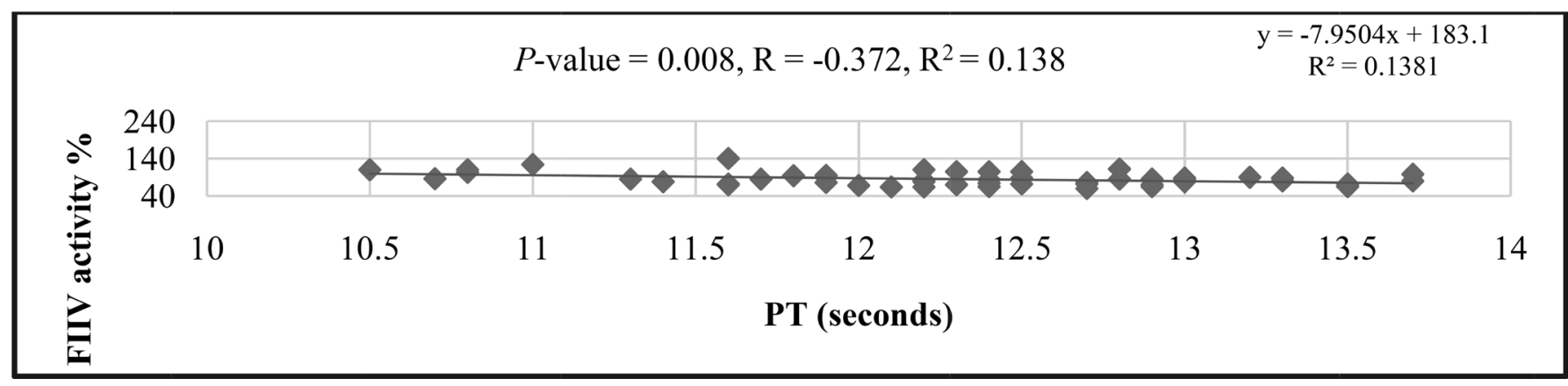

Figure 3 Correlation between FVII activity \% and prothrombin time

4. D-dimer level. The mean of D-dimer levels of the non-obese and obese groups $(212.8 \pm 122.5 \mathrm{ng} / \mathrm{ml}$ and $301 \pm 338.8 \mathrm{ng} /$ $\mathrm{ml}$, respectively) were higher than that of control group (155.8 $\pm 31.6 \mathrm{ng} / \mathrm{ml}$ ) with statistical significant differences with P-values 0.029 and 0.038 , respectively (Table 2).

$>$ The distribution of cases according to their D-dimer level. According to the D-dimer level, of the 50 cases studied, 39 $(78 \%)$ of them had normal D-dimer level $(250 \mathrm{ng} / \mathrm{ml})$ while it is increased in the others; in $6(12 \%)$ the level was $250-500$ $\mathrm{ng} / \mathrm{ml}$, in $4(8 \%)$ the D-dimer level was $>500-1000 \mathrm{ng} / \mathrm{ml}$, and only one ( $2 \%$ ) had D-dimer level $>1000 \mathrm{ng} / \mathrm{ml}$ (Figure 4). In the control group the D-dimer levels were $<250 \mathrm{ng} / \mathrm{ml}$ in all of them.

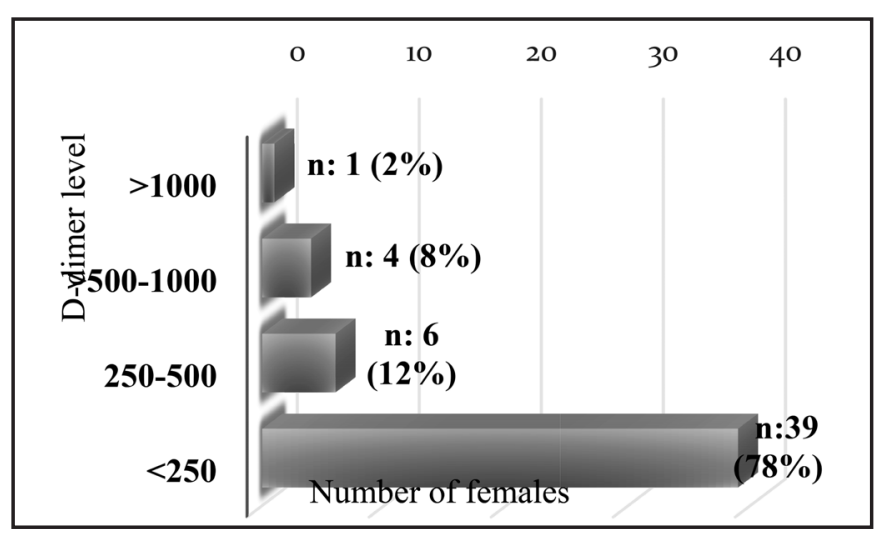

Figure 4 The distribution of the 50 females on COCPs by their D-dimer level

5. The platelet count. The mean PLT in the non-obese group was $305.960 \pm 65.999 \times 10^{9} / \mathrm{L}$ and in control was $279.40 \pm$ $46.329 \times 10^{9} / \mathrm{L}$ with statistically insignificant difference $(\mathrm{P}=$ 0.106). While for the obese group, the mean PLT was 313.480 $\pm 58.468 \times 10^{9} / \mathrm{L}$ which was significantly higher than that of control with P-value 0.027 (Table 2).

C. The comparison of the hemostatic parameters between the obese and the non-obese cases.

There were no statistically significant differences in the means of PT, APTT, Factor VII activity, D-dimer level, and PLT between the non-obese and obese groups (Table 3 ).
Table 3 The hemostatic parameters (mean values \pm SD) in the obese and non-obese cases

\begin{tabular}{lcccc}
\hline \multicolumn{1}{c}{ Hemostatic Parameter } & $\begin{array}{c}\text { Obese cases } \\
(\mathrm{n}=25)\end{array}$ & $\begin{array}{c}\text { Non obese } \\
\text { cases } \\
(\mathrm{n}=25)\end{array}$ & P-value \\
\hline PT (seconds) & & $12.4 \pm 0.7$ & $12.3 \pm 0.9$ & 0.663 \\
\hline APTT (seconds) & & $28.4 \pm 2.9$ & $28.8 \pm 2.8$ & 0.597 \\
\hline FVII activity \% & $\mathbf{8 8 . 9} \pm 19.4$ & $\mathbf{8 1 . 2} \pm 13.7$ & 0.109 \\
\hline PLT (×10 $/ \mathrm{L})$ & $313.48 \pm 58.468$ & $305.96 \pm 65.999$ & 0.672 \\
\hline D-dimer (ng/ml) & $301.4 \pm 338.8$ & $212.8 \pm 122.5$ & 0.225 \\
\hline
\end{tabular}

\section{Discussion:}

The two study groups (non-obese and obese females) were aged-matched with control group to prevent the effect of age on thrombosis risk which is increased with increasing the age $[9,19,20]$. The difference in BMI was statistically insignificant $(\mathrm{P}>0.05)$ between the mean BMI for the non-obese group and control to minimize the effect of increased BMI as a confounding factor in order to assess the effect of pills alone since literatures reported increased tendency for thrombosis with obesity $[2,5,20]$. The mean PT of the non-obese and obese groups both were found to be significantly shorter than that of control ( $\mathrm{P}=0.014$ and 0.020 , respectively). This goes with AL-Husaynee AJ et al. (Iraq, 2006) [21], Babatunde AS et al. (Niger, 2004) [22], and Roshidah I et al. (Malaysia, 1990) [23]. While Afsar NA et al. (Pakistan, 2003) [24] observed insignificant reduction of $\mathrm{PT}$ in pills users $(\mathrm{P}=0.207)$. When the PT of the studied groups was compared with the lower limit of PT in the control group (11.8 seconds) we noticed that $7 / 25(28 \%)$ of the non-obese group and $4 / 25(16 \%)$ of the obese group had shortened PT. The observed shortening of PT in the females may be explained by the procoagulant effect of the used pills that includes the increased plasma levels of several coagulation factors including fibrinogen, prothrombin, FVII and FX $[2,4,6,25]$. The concentration of these factors are known to affect the extrinsic pathway of the coagulation and hence the PT [17]. Insignificant correlations were found 
between PT and duration of use, both during the first year and with the use for 1 year or more $(\mathrm{P}>0.05)$. These results differ from those obtained by AL-Husaynee AJ et al. (Iraq, 2006) [21] who reported a significant negative correlation between PT and duration of use of oral contraceptive. This discrepancy may be attributed to the type of the pills and their contents which were used by the females; in our study the pills contained lower doses of estrogen and progestin $(0.03 \mathrm{mg}$ ethinylestradiol and 0.15 mg levonorgestrel), while in AL-Husaynee AJ et al. study the females used pills that contained $0.05 \mathrm{mg}$ ethinylestradiol and $0.25 \mathrm{mg}$ levonorgestrel. The thrombosis risk in COCP users is increased with increasing the estrogen dose $[5,10]$. In addition to this, the risk is not cumulative with use [2]. The difference in the mean APTT between non-obese and control, and obese and control didn't show statistically significant differences $(\mathrm{P}>0.05)$. These results are comparable to those conducted on Nigerian women, 2004 study [22] but differ from those obtained by AL-Husaynee AJ et al. (Iraq, 2006) [21], Roshidah I et al. (Malaysia, 1990) [23], and Afsar NA et al. (Pakistan, 2003) [24] who observed significant reduction of APTT in women using the COCPs because the plasma concentration of several markers of coagulation including FVIII and FX have been shown to be higher in pills users compared with non-users [21]. It had been observed that $2 / 25(8 \%)$ of females in the nonobese group and 2/25 (8\%) of females in the obese group had shortened APTT compared to the lower limit of APTT in the control (24.6 seconds). Our results may be referred to the low estrogen content in the pills as the thrombotic risk is increased with increasing estrogen dose [4,9]. In addition, the difference in number of cases studied may be the cause of this discrepancy. Insignificant negative correlations have been noticed between the APTT and the duration of pills use both during the first year and with prolonged use $(\mathrm{P}>0.05)$. In a Pakistanian study 2003, Afsar NA et al. observed negative correlations between the APTT and the duration of pills use both during the first year and with prolonged use, but with statistical significance only during the first year of using COCPs [24]. This discrepancy in these results may be attributed to different study population. The mean FVII activity observed in the non-obese group and in the obese group were higher than that in the control group with statistically significant differences $(\mathrm{P}=0.041$, and 0.001 , respectively). Junge $\mathrm{W}$ et al. [26] and Klipping $\mathrm{C}$ et al. [27] observed the increase in factor VII activity after 3 months of using the pills, while Roshidah I et al. [23] noticed that there was no significant difference in FVII activity between users women and control group. Factor VII is one of the coagulation factors that may be increased in COCPs users as a result of the procoagulant effect of these pills $[2,4,6,25]$. For all 50 studied females, there was significant inverse correlation between FVII activity and PT $(\mathrm{P}=0.008)$. In this study, the observed mean of $\mathrm{D}$-dimer level in the non-obese group and obese group were significantly higher than that in the control group $(\mathrm{P}=0.029$ and 0.038 , respectively). These results were comparable to those reached by AL-Husaynee AJ et al. who reported significantly positive D-dimer in users than non-users [21]. Meijers JC et al. also found significant increase of D-dimer during the use of the pills [28]. Junge $\mathrm{W}$ et al. [26] and Klipping C et al. [27] observed the increase in D-dimer level after 3 months of pills use, but it was insignificant in Klipping $\mathrm{C}$ et al. study. The females using the combined contraceptive pills have enhanced fibrinolytic activity $[4,6,25]$ that may explain the significantly high D-dimer levels. The mean PLT in the non-obese group was higher than that in the control, but this didn't reach the level of statistical significance $(P=0.106)$, while the obese group had significantly higher PLT than that of control group $(\mathrm{P}=0.027)$. Al-Husaynee AJ et al. (Iraq, 2006) [21] and ALChalaby SAH (Iraq, 2001) [29] found significantly higher PLT in COCPs users than non-users regardless the BMI. In a Nigerian study carried to determine the effect of low-dose COCPs on some hemostatic parameters of apparently healthy women over a period of three months, the mean value of PLT was significantly increased after three months of contraceptive use [22]. Afsar NA et al. found the increase in PLT was insignificant in users group than non-users [24]. Shafiq M et al. noticed insignificant rise in the PLT after 6 months of pills [30]. Another researcher in Nigeria in 2014 [31] published that the mean of PLT was marginally higher among subjects on hormonal contraceptives compared to controls, however this difference was statistically insignificant $(\mathrm{P}=0.851)$. These results can be explained by the fact that the PLTs have estrogen beta receptors. This implies that PLT function may be modulated by sex hormone levels [32]. Estrogens have a week anabolic effect which can potentially suppress the actions of other reproductive hormones like luteinizing hormone and follicle stimulating hormone and prevents ovulation [30,31]. Estrogen therapy especially with higher doses of synthetic estrogens in oral contraceptives has been shown to increase PLT, platelet aggregation and to enhance clot formation [29]. There were no significant statistical differences for all studied parameters (PT, APTT, FVII, D-dimer level, PLT) between obese and nonobese groups. This probably because the differences in the BMI were not wide and the non-obese group included females with overweight, but this was defeated by the presence of significant statistical differences between the non-obese group and control group (as the later also included females with overweight). The absence of significant differences between the obese and nonobese groups accentuates the effect of COCPs on the study groups when compared with the control group. Obesity still has increased thrombosis risk which probably become more evident when studied and compared with normal BMI females, as overweight increases thrombosis risk [2,13].

In conclusion, the use of the COCPs is associated with some degree of enhanced procoagulant activity. Therefore, females should be properly assessed and monitored before starting using the pills and while on them. 


\section{Author contributions:}

Haithem Ahmed MJ Al-Rubaie, FICMS-Pathology (Hematology), consultant hematopathologist and assistant professor in the Department of Pathology, College of Medicine, University of Baghdad, the supervisor.

Israa Saadi Abbas, MSc, Hematopathologist, Abi-Ghraaib General Hospital, the researcher.

Jaffar Nouri Jaffar Al alsaidissa, PhD Pathology (Hematology), lecturer, Department of Pathology, College of Medicine, University of Baghdad, involved in revising the article for important intellectual content.

All authors approved the final version to be published.

\section{References:}

1. The New York Times. Birth Control Overview. NY Times 18 February 2015. http://www.nytimes.com/health/ guides/specialtopic/birth-control-and-familyplanning/ oralcontraception-and-combination-hormonal-methods.html\# (accessed 20 February 2015).

2. Rosendal FR, Van Hylckma VA, Tanis BC, Helmerhorst FM. Estrogens, progestogens and thrombosis. J Thromb Haemost 2003; 1(7): 1371-1380. http://onlinelibrary.wiley. com/doi/10.1046/j.15387836.2003.00264.x/full (accessed 23 December 2014).

3. Marnach ML, Long ME, Casey PM. Current issues in contraception. Mayo Clin Proc 2013; 88(3): 295-299. http:// www.mayoclinicproceedings.org/article/S0025-6196(13) 00063-3/pdf (accessed 5 May 2015).

4. Rosendaal FR, Helmerhorst FM, Vandenbroucke JP. Female hormones and thrombosis. Arterioscler Thromb Vasc Biol. 2002; 22: 201-210.

http://atvb.ahajournals.org/content/22/2/201.long (accessed 11 February 2015).

5. Rathbun S. Venous thromboembolism in women. Vascular Medicine 2008; 13: 255-266. http://vmj.sagepub.com/ content/13/3/255.full.pdf (accessed 16 February 2015).

6. Trenor CC, Chung RJ, Michelson AD, Neufeld EJ, Gordon $C M$, Laufer MR, Laufer MR et al. Hormonal contraception and thrombotic risk: a multidisciplinary approach. Pediatrics 2011; 127(2): 347-357.

http://www.ncbi.nlm.nih.gov/pmc/articles/PMC3025417/ (accessed 8 January 2015)

7. Lidegaard Ø, Løkkegaard E, Svendsen AL, Agger C. Hormonal contraception and risk of venous thromboembolism: national follow-up study. BMJ 2009; 339: b2890.

http://www.bmj.com/content/339/bmj.b2890 (accessed 14 March 2015).

8. Guida M, Bifulco G, Sardo ADS, Scala M, Sosa LM, Fernandez, Nappi C. Review of the safety, efficacy and patient acceptability of the combined dienogest/estradiol valerate contraceptive pill. Int J Womens Health 2010; 2: 279-290. http://www.ncbi. nlm.nih.gov/pmc/articles/PMC2990895/ (accessed 19 December 2014). IVSL
9. Jick SS, Hernandez RK. Risk of non-fatal venous thromboembolism in women using oral contraceptives containing drospirenone compared with women using oral contraceptives containing levonorgestrel: case-control study using United States claims data. BMJ 2011; 340: d2151.

http://www.ncbi.nlm.nih.gov/pmc/articles/PMC3081040/ (accessed 5 February 2015).

10. World Health Organization. Obesity and overweight. http://www.who.int/mediacentre/factsheets/fs311/en/(accessed 18 February 2015).

11. Mayo Clinic Staff. Obesity. http://www.mayoclinic. org/diseases-conditions/obesity/ basics/definition/con20014834? reDate $=12072015$ (accessed 15 January 2015).

12. Murthy AS. Obesity and contraception: emerging issues. Semin Reprod Med 2010; 28(2): 156-163. doi: 10.1055/s0030-1248141. Epub 2010 Mar 29 (accessed 15 December 2014).

13. Abdollahi M, Cushman M, Rosendaal FR. Obesity: risk of venous thrombosis and the interaction with coagulation factor levels and oral contraceptive use. Thromb Haemost 2003; 89(3): 493-8. http://www.researchgate.net/publication/10866426 Obesity_risk_of_venous_thrombosis_and_the_interaction_ with_coagulation_factor_levels_and_oral_contraceptive_use (accessed 24 November 2014).

14. Brummel-Ziedins KE, Orfeo T, Everse SJ, Mann KG. Blood Coagulation and Fibrinolysis. In: Greer JP, Arber DA, Glader $B$, List AF, Means RT, Paraskevas F et al (eds). Wintrobe's Clinical Hematology. 13th ed. Lippincott Williams \& Wilkins 2015; 970-1172.

15. Adam SS, Key NS, Greenberg CS. D-dimer antigen: current concepts and future prospects. Blood 2009; 113: 2878-2887. http://www.bloodjournal.org/content/early/2008/11/13/blood2008-06-165845? sso-checked=true (accessed 4 December 2014).

16. Riley RS, Tidwell A. D-dimer assays. http://www.pathology. vcu.edu/clinical/coag/D-Dimer.pdf (accessed 18 February 2015).

17. Laffan M, Manning R. Investigation of haemostasis. In: Bain BJ, Bates I, Laffan MA, Lewis SM (eds.). Dacie and Lewis Practical Haematology. 11th ed. Philadelphia: Churchill Livingstone Elsevier 2011; 393-445.

18. Test ID: DDI, D-Dimer, Plasma. http://www. ma yo medical la boratories.com/te st-catalog/ Clinical + and + Interpretive/9290 (accessed 3 February 2015). 19. Previtali E, Bucciarelli P, Passamonti SM, Martinelli I. Risk factors for venous and arterial thrombosis. Blood Transfus 2011; 9: 120-138.

http://www.ncbi.nlm.nih.gov/pmc/articles/PMC3096855/ (accessed 6 June 2015).

20. Pinjala RK, Reddy LRC, Nihar RP, Praveen GVA, Sandeep M. Thrombophilia - how far and how much to investigate? Indian J Surg 2012; 74(2): 157-162. http://www.ncbi.nlm.nih. gov/pmc/articles/PMC3309100/ (accessed 3 January 2015). 
21. AL-Husaynee AJ, Kashmoola MA. Effect of combined oral contraceptive pills on some haemostatic parameters. Ann. Coll. Med. Mousl 2007; 33(1\&2): 66-69. www.iasj.net) iasj?func $=$ fulltext\&aId $=8834$ (accessed 13 December 2014). 22. Babatunde AS, Olatunji PO. Short-term effect of oral contraceptive pills on some haemostatic parameters in healthy Nigerian women. Niger Postgrad Med J 2004; 11(4): 246-50. http://www.ncbi.nlm.nih.gov/pubmed/15627149 (accessed 19 November 2014).

23. Roshidah I, Khalid H, Baharum Y. Coagulation profile in women on low-dose oral contraceptive pills. Malaysian Journal of reproductive health 1990; 8(2): 97-100. www. popline.org/node/374839 (accessed 13 March 2015).

24. Afsar NA, Barakazai Q, Adil SN. Effect of low dose oral pill on haemostatic parameters in a set of Pakistani population. JPMA 2008; 58(5): 229-233.

http://jpma.org.pk/full_article_text.php?article_id= 1387 (accessed 6 May 2015).

25. Vandenbroucke JP, Rosing J, Bloemenkamp KWM, Middeldrop S, Helmerhorst FM, Bouma BN et al. Oral contraceptives and the risk of venous thrombosis. $N$ Engl J Med 2001; 344(20). http://www.nejm.org/doi/pdf/10.1056/ NEJM200105173442007 (accessed 15 March 2015).

26. Junge W, Heger-Mahn D, Trummer D, Merz M. Investigation of the hemostatic effect of a transdermal patch containing $0.55 \mathrm{mg}$ ethinylestradiol and $2.1 \mathrm{mg}$ gestodene compared with a monophasic oral contraceptive containing $0.03 \mathrm{mg}$ ethinylestradiol and $0.15 \mathrm{mg}$ levonorgestrel: an open-label, randomized, crossover study. Drugs $R$ D. 2013; 13(3): 223233. http://www.ncbi.nlm.nih.gov/pmc/articles/PMC3784047/ (accessed 22 March 2015). IVSL

27. Klipping C, Duijkers I, Parke S, Mellinger U, Serrani $M$, Junge $W$. Hemostatic effects of a novel estradiol-based oral contraceptive, an open-label, randomized, crossover study of estradiol valerate/dienogest versus ethinylestradiol/ levonorgestrel. Drugs R D 2011; 11(2): 159-170. http://www. ncbi.nlm.nih.gov/pmc/articles/PMC 3585947/ (accessed 10 May 2015). IVSL

28. Meijers JC, Middeldorp S, Tekelenburg $W$, van den Ende AE, Tans G, Prins MH et al. Increased fibrinolytic activity during use of oral contraceptives is counteracted by an enhanced factor XI-independent down regulation of fibrinolysis: a randomized cross-over study of two low-dose oral contraceptives. Thromb Haemost. 2000; 84(1): 9-14. http://www.ncbi.nlm.nih.gov/pubmed/10928462 (accessed 22 November 2014).

29. Al-Chalaby SSH, Taib SM, Ahmed AF. The effect of oral contraceptive pills on haematological indices running title: haematological parameters in oral contraceptive users. Tikrit Med J 2006; 12(1): 65-69. http://www.iasj.net/ iasj?func $=$ fulltext\&aId $=21963$ (accessed 22 November 2014)

30. Shafiq M, Hassan SH, Zubair M, Aziz Q. Combined oral contraceptive pills produce fewer changes in platelet count. http://pjmhsonline.com/JanMarch2012/combined__oral_ contraceptive_pill.htm (accessed 5 November 2014).

31. Isaac IZ, John RT, Suleiman AS, Erhabor O, Yakubu A. The effect of hormonal contraceptives on platelet count of women in Sokoto State North Western Nigeria. Merit Research Journal of Medicine and Medical Sciences 2014; 2(1). http:// www.researchgate.net/publication/259494544_The_effect of_hormonal_contraceptives_on_platelet_count_of_women_ in_Sokoto_State_North_Western_Nigeria (accessed 8 July 2015).

32. Khetawat G, Faraday N, Nealen ML, Vijayan KV, Bolton E, Noga SJ et al. Human megakaryocytes and platelets contain the estrogen receptor $b$ and androgen receptor (AR): testosterone regulates AR expression. Blood 2000; 95: 2289-2296. http:// www. bloodjournal.org/content/95/7/2289.full-text.pdf + html (accessed 8 July 2015). 